\title{
NUMERICAL SIMULATION OF PHOTOCHEMICAL EPISODES IN ALPINE VALLEYS
}

\author{
Guillaume Brulfert, Jean-Pierre Chollet, Charles Chemel, and Marie- \\ Aurélie Kerbiriou*
}

\section{INTRODUCTION}

Alpine valleys are sensitive to air pollution due to emission sources (traffic, industries, individual heating), morphology (narrow valley surrounded by high ridge), local meteorology (temperature inversions and slope winds). Such situations are rarely investigated with specific research programs taking into account detailed atmospheric chemistry coupling gas and aerosol phases. Following the accident under the Mont Blanc tunnel on March $24^{\text {th }}, 1999$, international traffic between France and Italy was stopped through the Chamonix Valley (France). The heavy-duty traffic (about 2130 trucks per day) has been diverted to the Maurienne Valley, with up to 4250 trucks per day. The program POVA (Pollution des Vallées Alpines) started in May 2000, with the objective to analyse air quality and develop atmospheric modelling in each of the two valleys, in order to study impact of traffic and local development scenarios.

\section{MODELS}

Atmospheric prediction model ARPS 4.5.2 (Advanced Regional Prediction System), developed at CAPS (Center for Analysis and Prediction of Storms) (Xue, 2000), enables to resolve atmosphere dynamics above complex terrain. A large $(250 * 300 \mathrm{kms})$ field is driven by the ALADIN verticals of the French Meteorological Office and forces the field of interest $(25 * 25 \mathrm{kms})$. This model is coupled off-line to the TAPOM 1.5.2 code of atmospheric chemistry (Transport and Air POllution Model) developed at the LPAS of the EPFLausanne (Clappier, 1998; Gong and Cho, 1993). TAPOM uses the Regional Atmospheric Chemistry Modeling (RACM) scheme (Stockwell et al.,1997). 300-meters grid cells to calculate dynamics and reactive chemistry make possible to represent accurately dynamics in the valley (slope winds) (Anquetin et al., 1999) and to process chemistry at fine scale.

*G. Brulfert, J.P. Chollet, C. Chemel, and M.A. Kerbiriou, Laboratoire des Ecoulements Géophysiques et Industriels, Université Joseph Fourrier, Institut National Polytechnique de Grenoble et Centre National de la Recherche Scientifique, BP 53, 38041 Grenoble Cedex 9, France. brulfert@hmg.inpg.fr 


\section{SIMULATION OF PHOTOCHEMICAL EPISODES IN CHAMONIX VALLEY}

The emission inventory is based on the CORINAIR methodology and SNAPS's codes, uses a $100 \times 100 \mathrm{~m}$ grid and includes information (land use, population, traffic, industries,..) gathered from administrations and field investigations. The yearly inventory is turned into hourly emissions for a set of RACM data in specific cases (summer/winter, week day/week end/holidays, ...) to be used in scenarios (Middleton et al., 1990). Then, different scenarios are tested in the valley of Chamonix with various sources: with and without road traffic, with and without heavy vehicles, for different meteorological cases. Sunny days, without synoptic wind, explain the contribution of local sources of pollution with mixing by slope winds. Days with a constant synoptic wind in the bottom of the valley gives an insight into the pollution background and boundary conditions species. Dispersion of a passive tracer enables to describe how primary pollutants are either mixed inside the valley or transported beyond the limits of the valley. Preliminary results, without comparison with campaign data, show that typical species of secondary pollutants (HNO3, PAN) depend on road traffic and heavy -vehicles.

Several sensitivity tests are being performed, based on real variation of the gases emissions and background. The first results are very encouraging, when compared to fields measurements.

\section{CONCLUSION}

The objective of the program is now to estimate the respective impacts of the various emissions sources present in the valleys and evaluate the variability in air concentrations according to changes in environmental conditions. Then the same study will begin for the other valley of POVA program (Maurienne valley) and the impact of road traffic will be evaluated.

\section{ACKNOWLEDGEMENTS}

The program POVA is supported by Région Rhône Alpes, ADEME, METL, MEDD. Meteorological data are provided by Météo France, traffic data by STFTR, ATMB, DDE Savoie et Haute Savoie. Computations were done on MIRAGE (plate-forme grenobloise de modélisation numérique de l'environnement et du climat).

\section{REFERENCES}

Anquetin, S., Guilbaud, C., Chollet, J.P., 1999. Thermal valley inversion impact on the dispersion of a passive polluant in a complex mountainous area, Atmospheric Environnement 33, pp. 3953-3959.

Clappier, A., 1998, A correction method for use multidimensionnal time splitting advection algorithms : application to two and three dimensional transport, Monthly Weather Revue 126, pp. 232-242.

Gong, W. and Cho, H-R (1993) A numerical scheme for the integration of the gas phase chemical rate equations in a thre-dimensional atmospheric models, Atmospheric Environment 27A(14), pp. 2147-2160.

Middleton, P., Stockwell, W.R., Carter, W.P.L., 1990. Aggregation and analysis of volatile organic compound emissions for regional modelling, Atmospheric Environnement 24A, pp. 1107-1133.

Stockwell, R., Kirchner, F., Kuhn, M., Seefeld, S., November 27, 1997. A new mechanism for atmospheric chemistry modeling, Journal of Geophysical Research, vol. 102, No. D22, pp. 25,847-25,879.

Xue, M., Droegemeir, V., Wong, V., 2000. The Advanced Regional Prediction System (ARPS)- A multi-scale nonhydrostatic atmospheric simulation and prediction model. Part I : Model dynamics and verification, Meteorology and atmospheric physics, volume 75, Issue 3/4, pp. 161-193. 